\title{
Joint Custody in Families and its Pitfalls (from a research Perspective)
}

\section{Adriana Wiegerová, Dana Hamplová}

\begin{abstract}
The divorce of their parents is a fundamental event in the lives of many children. This is a very difficult time for all those involved. However, society still tends to see divorce as a "normal thing". For parents and children, however, it is not, as it disrupts their day-to-day lives. The parents are immersed in their feelings and deal with "practical matters", while the children can be overlooked. The question of joint custody and the impact this model has on children of pre-school age is presented through the results of research carried out in 2013 and 2014. The research was qualitatively oriented. This study presents our findings, obtained through in-depth interviews with the parents of pre-school children who have requested joint custody.
\end{abstract}

Keywords: joint custody, pre-school children and younger schoolchildren, divorce, parents, family

\section{Introduction and theoretical background}

If parents split up and get divorced, their rights and duties in relation to their child or children have to be defined. The parents start to find out information about possible types of upbringing. It is clear from the statistics that parents often request the form of joint custody. Joint custody is one form of caring for children when their parents live separately after the divorce or break-up (Amato, 2010). Joint custody has been in place for a long time, particularly in the countries of Western Europe, Scandinavia, Canada and 
the USA (since the mid-1980s). In this form of case the parents still have an influence over the child's upbringing and are in close contact with the child. However, does the media show all the sides of joint custody? Are children happy in joint custody, or is it just that the parents are satisfied that they have got their own way? Are parents adequately informed about the essence and conditions of joint custody?

Children are always affected by their break-up of their parents. Children notice tension or strife between their parents and are aware when one of them leaves. In the midst of a divorce parents can often be wrapped up in their emotions and have to deal with a lot of different problem (e.g. job, housing, finances, etc.). In this situation they have less time to devote to their children and can be less empathetic to their children's needs.

The Civil Code states that when decisions are made concerning custody, the court should ensure that the decision made is in the interests of the child. The court should take account of the child's personality, talents and abilities in relation to the development potential and living situation of the parents. Each parent may have differing income, housing options, etc. The court should also take the child's emotional stability into consideration. A child is an individual, so should be treated as such. Some children, for example, do not like changes, while others have no problem accepting them. The court should also explore each parent's ability to bring up the child, and should monitor the current and anticipated stability of the family environment in which the child is to live. The child does not only live with its parents, but also with siblings, grandparents, other relatives. Therefore, the court should also take an interest in the emotional ties the child has with these people. It should also ascertain which of the parents has done a proper job of looking after the child up to that point, including the child's emotional, intellectual and moral education, as well as which parent offers the child better potential for healthy and harmonious development. In cases of joint custody the child's opinion should always be sought. The court's decision should not be a concession for one of the parents in cases of rivalry.

It is primarily down to the parents to prove that joint custody can work in practice before the court makes its decision. According to Klimeš (2009, pp. 13-14), it is best if the custody intervals are as similar to a normal way of life as possible. It sees half-day intervals as being most suitable, but in most cases this is not practical. In the case of pre-school children and younger schoolchildren, where the intervals tend to be weekly, family meetings during the week are suitable. This, however, calls for mature communication between the parents.

Before the joint custody decision is issued, the parents should answer a few of the following questions (compiled according to Zakouřilová, 2014, pp. 176-178):

Where will the child be registered as living?

What will change with a new partner, how will that partner get on with the children, what will that partner's attitude to this specific form of upbringing be? 
Is there adequate information about joint custody, is it clear whom I need to contact for assistance in reaching an agreement with the other parent?

Is the child adequately adaptable, more sensitive, prone to anxiety, closer to one particular parent, at the right age, is the child's health good enough for joint custody or could this have an adverse impact on the child's health?

Who will buy the child's clothes, pay for hobby groups and other activities?

What will happen with the child during the school holidays, on public holidays and birthdays?

How can the parents cope financially with paying for housing?

Who will communicate with the (nursery) school?

Who will claim tax benefits for the dependent child?

According to Hrušáková and Novák (1999, pp. 32-34) it is essential that the parents show their ability to cooperate with the other parents. Words are not enough. They also claim that sufficient attention should be given to the opinions of the child.

Housing conditions should be comparable, so that the child does not have the sense of being "bought".

On the subject of joint custody there is also much discussion over the age of the child. According to Klimeš $(2009$, p. 2), the lowest age for joint custody is 3, i.e. an age when the child is ready to attend nursery school. Klimeš also states that until that time the child should fall asleep with the same parents and in the same environment.

In the case of pre-school children it is essential bear in mind the fact that joint custody should not be approved if we know that it will not be possible for us when the child is of school age.

Joint custody has its opponents as well as its supporters. Špaňhelová (2005, pp. 4-5) states that when joint custody is set up properly, when the parents cooperate well and when the child is well adapted to the situation there is a good chance that the child's emotional development will not be slowed or distorted. Children can learn from their parents how to deal with their emotions, they do not lose their sense of certainty, they still have a mutual relationship with their mother and father and still experience both male and female roles and elements of their upbringing. The child also sees behavioural models in both parents.

The mother and father are the most important people in a child's life. The mother and father's influence on the child is wholly irreplaceable. Each parent generally has a different style of upbringing, from which the child absorbs a certain model of behaviour. From their mothers children learn how to be a woman and how to communicate with women, while their fathers can teach them how to communicate with men and how to be a man. This teaches children how the opposite or same sexes communicate with one another. Research has also shown that both parents are irreplaceable, as the child develops a completely different relationship with both parents. Warshak (1996) 
even claims that children should grow up in the case of same-sex parents. Research carried out in the USA has shown that boys who grow up with their father do not have the same problems with integrating into society as boys raised by their mothers do. Of course, this information cannot be generalised and it is not always necessary to place boys in the care of their father. However, if a boy is placed in the care of his mother, it is essential that he retains regular contact with his father. This opens up the option of joint custody, where each parent has an equal right to care for their child.

The pitfalls of joint custody can be seen when joint custody is applied with very small children. Problems with this type of upbringing also include the fact that children can end up feeling more tired from travelling between one parent and the other.

Joint custody should not be a"victory" for one parent over the other when settling their disputes. The early stages of joint custody are difficult for all the members of the family.

Our study presents the experiences of parents who have opted for joint custody.

\section{Research methodology}

The aim of the research is to get an insight into parents' thoughts when choosing joint custody and clarify their reasons for choosing this system both when filing the proposal with the court and during the actual process of joint custody itself.

Previous research into joint custody has mostly been quantitatively oriented, and used questionnaires. It has focused mainly on the advantages and disadvantages of joint custody, on determining the professional experience of people with an interest in proceedings concerning children placed into the custody of both parents (Luňáčková, 2011, Špaňhelová, 2005). The aforementioned research gives us less of an insight into the motives of the parents themselves, i.e. what led them to opt for joint custody, how they manage it in practical terms, and what pleasures and pitfalls they have encountered. We were interested in how parents see the system of joint custody after entering into it. We were also interested in why parents file an application for joint custody and how they subjectively view the changes that occurred after commencing joint custody.

Due to the aim of the research, we collected the data through unstructured interviews. We did not have the questions prepared in advance, or the order in which they were asked.

The interviews were recorded on a dictaphone and then transcribed. In the next phase of the research we analysed the data and then continued by designating codes, sorting and systemizing subcategories and categories using open coding.

In order to be better prepared for interviewing the selected participants, we held an initial interview outside the research group. This was held with a pre-arranged participant who met the conditions. Joint custody had to have been approved by the 
court. Then, we arranged a place and time for the interview. At the beginning of the interview the participant was informed about the aim of the research and that the interview would be recorded. The interview started with an initial informal conversation, which was not recorded on dictaphone. We saw this part as being important, as it built a sense of trust and a good atmosphere. The interview itself lasted for roughly one hour. After interview was over, there was then another informal interview, which was again not recorded on the dictaphone. In this part the participant had the chance to ask the researcher questions, was interested in the researcher's practical experience of other families with joint custody. This part lasted for around half an hour.

In the research itself we then contacted several pairs of parents-participants, always a father and a mother, the condition being that the parents had joint custody approved by the court and that both parents agreed to the interview. Three pairs of parents agreed out of all the potential participants we contacted. We let the participants choose the place and were flexible to their needs as far as the location and time were concerned. The interviews were held in the participants' homes, as well as in quiet cafés. The research set comprised a total of 6 participants, 3 women and 3 men. All the participants were formerly husband and wife and had a court-approved agreement placing the children into the joint custody of both parents.

\subsection{Characteristics of the research set}

\section{Family 1}

The parents started to live together after knowing each other for four months, and got married after three years. Their daughter Ema was born after their first year of marriage. The mother had a miscarriage once before her daughter was born. According to the mother, the parents started to have disagreements around 2 years after their daughter was born. The parents longed to have another child, but the mother had two miscarriages. The mother told the father that she was unhappy in their marriage in around February 2012. The father tried to keep the marriage going, and started to visit a marriage counselling centre. The mother went once, but did not see it as important. The parents did not communicate well together, and did not talk about their problems together. The mother was afraid to express her feelings to the father. For the father it was a surprise that the mother wanted to leave; he could not understand it. Both parents agreed that they had never imagined they would one day get divorced.

Father 1 was 33 years old, university educated, a designer-electrical engineer by trade. He came from a complete family, and had younger sibling. The father tried to hold the marriage together and started to visit a marriage counselling centre. After the mother left the family home he met a new partner, who also had children in joint custody, although the father says that relationship was on the rebound, and only lasted for 9 months or so. The father now has a new girlfriend, who has not children and gets 
on well with his daughter. The father is happy in the relationship, and longs for another child. He keeps in contact with the mother's parents, but only formally. He lives in a flat in the town.

Mother 1 was 29 years old, with a secondary school leaving certificate, and was self-employed. She came from a complete family and had a brother 3 years younger than her. The mother and the father started to live together after knowing each other for around 4 months; she had wanted to move away from her parents, start a family and have children. She built her relationship with the father on practical things - the father's ability to provide for the family, his easy-going nature, etc. The mother now knows that a relationship cannot be built on these things alone. Miscarriages were psychologically demanding for the mother, and she had no support from the father. The mother did not want to go back to her original job, which she felt was too time-consuming for a mother with a child. The father had the opposite opinion. For the mother this sequence of events was probably what made her decide to end her relationship with the father. The mother found another partner, with whom she has lived in a family house in a village since May 2012. The mother maintains formal contact with the father's parents.

Ema was 5 years old. She attended nursery school in the town. She used to go to a pottery group. She was looking forward to having a sibling, and got on well with her father's partner and her mother's partner. According to the mother, she is more sensitive, while according to the father she is livelier. Each parent's style of upbringing is different.

The parents agreed on joint custody, which they followed from May 2012 at short intervals ( $2-5$ days) and a long week (5-2 days). The mother moved out of the house she had shared with the father and started to live with her partner, who had two children that visited them for the weekend once every two weeks. There were no major problems with the joint custody. The parents filed a court application for joint custody, which was approved in February 2013. The parents had also entered into a property settlement agreement. The court decision on joint custody stipulated that custody of the child be shared at 1-week intervals. In July 2013 the mother informed the father that she no longer saw joint custody as being suitable for their child. She had already informed the father about changes in the child's behaviour (nightmares, unwillingness to go to nursery school, a tendency to cry when leaving her mother, etc.), although the father did not see any of this in the child.

\section{Family 2}

The parents got married after being together for a year, during which time they lived together. After a year of marriage their first son, Jan, was born, followed by their second son, Šimon, 21 months into the marriage. According to the mother the parents would have split up during her first pregnancy, if she had not been pregnant. The parents found it difficult to bring up their children, particularly during their first two years of 
age, which led to quarrels between the parents, a lack of communication, and complete alienation. The parents lived for the present and only thought about the situation in hand, and had not time for one another. This naturally led the parents to decide to get divorced. The father made an effort to save the marriage and wanted to visit a marriage counselling centre, but the mother refused.

Mother 2 was 36 years old, university educated, worked as a general practitioner for adults, now on maternity leave. She came from a complete family, had a brother 5 years younger than her, who had Asperger's Syndrome. She never really experienced a proper sibling relationship. At the age of 14 the mother left home to study at a foreignlanguage grammar school, where she met other peers and had the chance to compare herself against them. She claimed that her family environment offered little in the way of stimuli, was not very sophisticated, and her childhood was very short. Her mother had always supported her. She did not mention her father during the interview. The mother was on parental leave for 5 years, and saw this as an exhausting and demoralising time. In retrospect, she sees her break-up with the children's father as the right decision, one which has benefited both parents. The mother has a new partner, with whom she is expecting twins. The mother's partner does not live with the mother, and stays with the mother and children a couple of days a week. The mother was obliging and communicative during the interview.

Father 2 was 38 years old, and was unemployed. He came from a complete family, which had always given him a lot of care and support. Nobody was divorced in his close or extended family. The father had an older sister, who had her own children; he got on well with them, and they lived on the same estate. He does not have a partner. He sees joint custody as a form of active parenthood, and has learnt a lot of skills (washing, cooking, ironing, etc.). The father is now happy. With the benefit of time, the father thought his divorce from the mother was a good thing.

Jan was 8 years old, attended the third class at elementary school. His period of defiance was a challenging time. Jan was a self-confident lad, able to express his opinion and had the tendency to manipulate others. The parents sometimes went to class meetings together. Matěj went to a swimming group.

Šimon was 7 years old, attended nursery school, and had been there at his enrolment, as had both his parents. According to his parents he was a very raucous child. He had less self-confidence than his older brother, but was cleverer, according to his parents. Šimon attended a gymnastics group.

\section{Family 3}

The parents moved to live with the father's mother after knowing each other for six months, as the mother, who was pregnant, was still studying. The mother was 20 years old when she had her first child - a girl. While studying daily the mother then had another child - a boy. Both children were unplanned. While the mother was studying, 
her mother helped out with looking after the children. The parents tried to live by themselves, but for financial reasons moved back the mother's father's house, where they lived for around 3 years. However, while they were living together they all (the mother, father, the father's mother) disagreed over various matters, and the mother even physically assaulted the father's mother. After this, the parents decided to go and live with the mother's parents in a family house in a village. The parents got married after being together for six months. The mother hoped that the father would change after the wedding. The mother did not want to get married, but the father did. Both the parents gave different reasons for the break-up of their marriage. The mother claimed it was because of differences over their sex life, when she was jealous of the father, while the father forbade her from doing various things and wanted to have control over the mother. The father believes that the reason was that the mother was unfaithful to him and was pregnant by someone else. There was also a lack of communication between the parents. After six months of marriage the parents got divorced, and the father moved into the town.

Mother 3 was 28 years old, trained as a chef-waiter. She came from a complete family, had no siblings, and was adopted. At the age of 15 she started to trace her biological family, although only managed to find out where she had been born, not whether she had any siblings. During puberty the mother had problems with her parents, but did not go into detail. The mother's parents were afraid that the mother would leave home. The mother realised that her parents were those who had brought her up. After her divorce she remarried, as she was expecting a baby - a little boy. The mother and her new husband shared a joint household in her parents' two-generation house. The mother is happy in the relationship.

The father 3 was 27 years old, and worked as a labourer. The father came from an incomplete family, and was raised by just his the mother. He knew his father, but had no contact with him. He had one brother, whom he saw regularly, and two sisters. He was not in any contact with one of the sisters. The father is the youngest of the siblings. He has no partner. He shares a home with his mother. He expects that the situation with the children will be sorted out by others, but has no suggestions of his own.

Anna was 6 years old, and attended nursery school in the village her mother lived in. She attended an art group. The mother took the child to a child psychologist because of her increasingly impulsive behaviour and the child's inability to sustain attention. The mother had informed the father about the visits to the psychologist, and the father was against it.

Bedrich was 3 years old, and was looked after all day long by his mother. He did not visit any hobby groups.

In February 2013 the mother filed an application with the court to obtain sole custody of the children. The father also wanted to have custody of the children himself. The court recommended that the parents visit a marriage counsellor, which they 
did, and made a joint custody agreement. Owing to the fact that the father worked shifts, the parents agreed on custody intervals of 4 and 4 days. The parents made an agreement concerning the court hearing in March 2013; the court ruled to approve the custody intervals proposed by the parents, with the proviso that as soon as Anna started school, the custody interval would be one week, and the school would have to be halfway between the parents' houses. Apart from some minor difficulties, joint custody worked well until Christmas 2013. As the father had changed his job, and due to his working hours on shifts, the joint custody agreement could not work as it had done previously. Care is now provided for both children mostly by the mother, and the father has contact with the children just one weekend every two weeks, which is what the parents agreed on. For this reason the mother filed an application with the court to have the arrangement changed and to obtain sole custody of the children.

\section{Interpretation of research findings}

\subsection{Joint custody agreement between the parents}

Parental agreement between the parents about joint custody is one of the most comprehensive rules made between the parents. We therefore believe that this is crucial, as it is during this phase that the parents make decisions, clarify their motivation, the reasons for and against, and try to obtain more information about joint custody.

In the case of family 1 , it was the mother that obtained information, mostly from the internet; during the interview the father said nothing about searching for information about this form of care.

I'd read lots of smart articles about how joint custody is great. Of course, some disagree, but I was also trying to work it so that I didn't take him away from his dad... I used to get so annoyed when I read the website "Where are you Dad" That this kind of website, you see... and I also used to read "Strídavka cz" and tried to get a grasp on it. But it's just that I think that it can't help unless people can understand the situation you're in. You can't be helped by someone from outside. It has to come from yourself. And that only thing that helps is not to stir up any conflicts, which is what all these organisations do. They all tell you: Protect and fight for your rights!" But that's not what it's about, and the child gets lost in all this. But most of all, both parents have to forget about ideas like: "I have rights." (M1)

Information was important for family 2 when setting up joint custody. The mother especially sought out examples of good practice, which encouraged her and strengthened her determination to opt for this type of upbringing. She was also aware of the individuality of each particular family. 
I tried to find some positive examples to show how it could work. I was always looking into it, and was attracted to those servers, where I searched for experience shared by people who eventually went through with the divorce and joint custody, to see if it could possibly work. I started by searching on the Rodina site to find stories about people who have joint custody and what they had to say about it. I really appreciated it, I guess I was just hungry to hear about stores where it worked. I also went through a time when I was always reading about what the best age is to get divorced. (M2)

In the interview the father again stress the importance of filtering and verifying information from various different websites. This information helped him to better prepare for joint custody. Individuality was also crucial for the father.

You see, I believe in common sense, as several times I've seen information on the internet that isn't very serious... it's good to check claims out and substantiate them somewhere else. You still have to look everything up for yourself, so you don't get swindled. What was probably most important at the beginning was that we read something about it, found out some information about what we were going into, we knew that where we were headed was a really individual thing. And this is the case with the information that I say should be filtered and analysed, as this information is not correct. (F2)

Family 3 had not found out any information about joint custody, and had not looked for it.

No, because I don't know, like... that you have to go to the social and they should tell me where to find out, but at the moment I don't want to stick my nose in too much. (F3)

No. We were somehow told that we'd be having joint custody. (M3)

As can be seen from the answers given by the research participants, information was important for the university-educated parents. What was interesting about the interview was discovering what parents expect from joint custody.

This can be summed up as follows:

expectations that the situation will calm down, resolving formal errors in property settlements, faith that joint custody works.

\subsection{Changes in the father and mother's new living situation}

This study presents a look at the position of the father and that of the mother in cases of joint custody. One does not imagine getting divorced when one gets married. Almost all of the participants said this.

I would never have thought that it would go so far that I'd end up getting divorced. (F1) 
One parent was surprised that the other parent left, but that parent had lived with the other for some time, had dealt with it emotionally, had thought about ending the relationship, and had weighed up the options involved in remaining in the marriage or leaving.

... I was unhappy... but I still wanted to do something to save that relationship. I never thought l'd get divorced. (M1)

... I was sorry about $i$ t, and also because of the children... (M3)

All the participants were shocked and surprised that their marriage had ended and one of them had left.

Both the fathers' and mothers' lives changed, and these new situations had to be dealt with:

a new partner,

other children with a new partner,

orientational family.

In our research it was the mothers who decided to end the marriage. Half of them already had another partner while still married. Finding a new partner was the culmination of their marital problems, when they were searching for something their husband did not give them or lacked, or had other expectations.

... I didn't get anything out of that relationship intellectually, as we were both different and had different educations, and both needed to talk about other things and other interests... You generally get over the fact that you don't have anyone, or it can be hard to get over, but that's what I did. (M2)

He's kind, all that, l love him and he loves me, too. (M3)

During their marriage the participants had thought about ending it, but were always prevented from doing so by health issues, the mother getting pregnant, or rashness.

... I had a miscarriage. And that was really the last straw. It was like destiny was telling me that it wasn't to be. I had my third miscarriage. And that's very hard, psychologically. (M1)

I can well remember the breaking point, when I was about 4 months pregnant with Jan, and I and the father had a talk, after which we split up, as if I wasn't pregnant. There were various breaking points, really. We probably wouldn't have been together if we hadn't had the child. (M2)

All the participants (mothers and fathers) who are in a relationship with a new partner are satisfied. They did not want to be alone, and wanted to spend their lives with someone. Therefore, divorce can be described as the culmination of a crisis, but did not signal a desire for an isolated, single life. 
I'm completely satisfied as far as my relationship goes. I didn't want to be alone and I know that I wouldn't be in such a hurry to get divorced now. (F1)

Of course, if a parent had a new partner, the children also had to get to know them. All the participants saw their childrens's relationships with their new partner in a positive light.

And the children say nice things about him, her boyfriend. (F2)

Ema likes my new girlfriend, they get on well, and are fond of one another. (F1)

Uncle plays with them, when he can, he's kinder. He's never raised his hand to them. The first time will be the last time. He's fine, he plays with them and we go out. (M3)

The participants did not mention the influence their new partner has on the children's upbringing. At the time of the interview all the mothers had another child with a new partner or were pregnant.

Often featuring in our interviews were the parents' orientational families, i.e. the families in which the parents grew up and were raised. The participants had various different role models in their families, identified with them, and adopted certain forms of behaviour into their own family life.

... I'm adopted, so I don't know... but if I have a sister or a brother, I have no idea. (M3)

... I just don't get on with my family... I left home at 14, I'm different, and it's great for a visit once a month or so. My mum's always supported me, I suppose... my childhood was awfully short. (M2)

\subsection{Position of the child in joint custody}

The participants perceived their children's feelings and behaviour differently, some with more sensitivity, others with less.

We present a borderline opinion, voiced by families 1 and 3 .

In family 3, for example, the father was unable to comment on his child's feelings and behaviour, as they had minimal contact.

I don't know, really, I can't say, as when I see them, I see them once a month. If I get to see them twice in a month, I'm happy. It's not a problem for me, as I live with my mum, I brought her to live with me because of the children. I call, when I have time, but I've not phoned them for ages, that's true. (F3)

Mother 3 spoke about how her child expressed herself.

No, I was playing with the ball, let's say, and it rolled it away, and dad saw it and little Béd'a got hold of it and I wanted to take it back and dad had a go at me, saying it was Béd'a's ball, but it was me who was playing with it and it's all my fault. I don't want to go and stay with him, he's a horrible dad. (M3) 
In family 1 the participants tried to take account of their child's feelings and behaviour. As mother 1 mostly looked after the child when she was ill and during the school holidays, she spent more time with the child, so she assumed that this closer and more frequent contact with her triggered a number of changes in the child.

... I'd say that she (the child) started to see it that she didn't want to go and visit him... (M1)

As we've already mentioned when discussing communication, the mother tried to describe their child's feelings and behaviour to the father, but the parents disbelieved one another's claims.

So I sent him an email, describing what she'd said. She was as afraid of her dad as I was. Now, she's more sensitive than I think she would be if it hadn't been like that. So it had to be really difficult for her. (M1)

We can see how the mother's feelings are transferred to the child, but also how communication between the parents is perceived by the child.

Ema was aware of a tense atmosphere. (F1)

\subsection{The real form of joint custody}

After hearing the descriptions of the real situations in these families we have extracted several important incidents and events. We focused on:

a) extraordinary situations,

b) the running of the household,

c) disharmony over upbringing.

Extraordinary situations primarily included situations where the child falls ill and the parents have to agree who will remain at home with the child. Illness can also disrupt the custody schedule. In the case of family 1 , the parents said that, when ill, the child was looked after by the mother when the father asked her to do so and she did not refuse. This however, subsequently led to misunderstandings between the parents. For the father, joint custody meant a certain order and system. The father used to go away on business trips, but said that his girlfriend could look after the child instead, an idea that the mother did not agree with.

As my wife had more free time, more flexible working hours, I always asked her if she could stay. Most of the time when Ema was ill, she used to stay at home, so I used to take one day time off in lieu, say. My ex-wife was mostly very accommodating to me. Little Ema likes my new girlfriend... And when I'm on a business trip, as I have that Tuesday, we agreed that my girlfriend would pick Ema up from nursery school and would take her there on Wednesday morning. That was before, and only very rarely, maybe once or twice (when the child was taken to the mother because she missed her during joint custody). Something like that did happen, but I backed down. The child, little Ema, can't just say "now I want to be 
there" - and we all then go crazy, reorganise our schedules and take Ema there. That week I had to somehow plan my work and other activities. (F1)

The mother stated that it was difficult in financial terms to stay at home with her child.

(M1) ... her dad never had her during the school holidays, when she was ill, and so on. And money was sometimes tight for me, as I couldn't go to work. (M1)

In the case of family 2 the parents coped with the difficult situation very well, according to the father. The grandparents also helped out looking after the children when they were ill.

(F2) He perhaps gets a bit better when he's with my wife, and then I get him with a cough, and that parent actively helps out, with everything - like illnesses and growing up... we get granny involved. My mum helps with the babysitting. But luckily those children aren't ill... When he has the 'flu, then sure, she stays with whoever she's with, he's got a temperature, so we don't bother about it, either I'm at home with him or my wife's at home with him. (F2)

The father and the mother from family 3 did not say much about care for the children during a time of illness. The father stated that he had asked the paediatrician about the children's health.

I sometimes go to see the paediatrician to ask, as I'd never hear it from her that they had the 'flu or something. (F3)

As far as the running of the household is concerned, we focused on where the parents lived, payments, the parents' jobs and incomes, passing on clothes to the children, the parents' visits to the homes of the other parent, cooperation with school, learning new things, more planned activities, etc.

Family 1 had agreed to split payments while they had joint custody.

I used to pay for the nursery school and fees, and my ex-wife paid for lunches or whatever was needed, so we used to go half and half, something like that.... when someone wants to have a child, they should have the money for it, or... I'm not saying that the child has to grow up in luxury, like, but a bloke should have some sort of secure job. I earn pretty good money, and my partner has a normal wage. (F1)

Well, at the beginning we tried...... he had a hundred thousand in the bank and I didn't have the money to buy washing powder. (M1)

In the case of family 2 both parents were actively involved in the child's upbringing and had a system for passing on clothes. However, both parents lived on the same housing estate, which is an important finding. 
... it's not far. The estate's the same, and the route is pretty much the same, too. Of course I had a better income, so I paid those bills for the children. Although now that income has changed for both of us. I'm on maternity leave and he's becoming self-employed, so I don't know, I suppose we'll always come to some sort of an agreement. We've got this handover bag, a clever thing, that you carry on your shoulder... The change means that one parent picks them up from nursery school, you see, while the other drops them off. And that bag contains what he took off them when he had them last time. So there are dirty clothes, which can just about fit into that bag, or some other things they had with them. But not jackets or boots, as they've only got one set of those, since why should we have everything twice? It's no problem at all for the kids and we just sling the bag over our shoulder when we leave with them. When they had more presents, bigger things, like when they got skis for Christmas, a satchel, and so on. So the father wrote and told me what he was buying and I gave him half for it. So for those bigger shared things, like skis, which you can obviously only have one pair of, we arrange it and we buy them. I appreciate it, and I'd say he does too, that we finally have some days to ourselves, which we never used to have. (M2)

The father made similar claims as the mother.

... me and my wife have everything twice. But expensive stuff like winter jackets, we've just got two. You start to plan more, l learned to plan my time so that the children spent the time actively. I learned to cook, and it works out cheaper. And they've got something at both of our places - they've got rabbits at my wife's, and construction kits at my place. It's more active for us, too, the parents, and easier to get an idea of what they're learning at school. I'm not talking about how I see it, how, but more how it is for the kids. Like we tell them well in advance. They know what they've got planned for the next fortnight or so. It's sort of more organised. And we keep each other informed, of course... So we know what's going on and where, and then there's the reading, so yeah, we read, we see that we have to like push those kids forwards. When I go and visit them, say... the lads want to show me some toys, so I go, like, I admire their crane, I fix a wheel here and there so that they can see I know my way around that second household... and that's kind of how it works. It's just a visit, after all. With her partner it's like the kids can see that their parents know about one another and aren't as sassy. We call it "swapping round", to kind of generalise it, so he'd understand. There has to be a mum and a dad, so that obviously puts me in the role of the mother. So, kiss it better, cuddle, have a snuggle, like... So yes, of course. You have to learn to cook, you know you have to rely on yourself. Whatever needs doing, do it. You learn some new recipes, don't you. And then you dish it up and: "I'm not going to eat that, I don't like it! (F2)

The primary issue for family was the difference in the parents' incomes. The parents did not disagree about clothes.

... as he had more money, he had more opportunity to buy her things, and he spoiled her, basically. So Anna was number one. Béd'a wasn't, Béd'a was still in nappies. At the beginning I used to give him things, as he did the shopping, wrote their names on the things so 
they wouldn't get confused. If it happen that he dressed them in clothes he'd bought, I used to wash them and put them on one side, so I didn't get confused. When he (the older child) has to go to his dad's, he takes off my glasses and wears his at his dad's. It worked, sometimes there were ups and downs, and so on, but that way it worked well." The father lives with his mother in the town, while the children's mother lives in a village. (M3)

It's not a problem for me, as I live with my mum, I brought her to live with me because of the children. I call, when I have time, but I've not phoned them for ages, that's true. (F3)

There were significant disagreements between the parents during joint custody. The parents disagreed over clothes, school attendance, diet, and the age at which children should be in joint custody, but also over financial matters. In the case of family 1 , disagreements mostly concerned how the child was being raised, i.e. when the child was placed in the mother's care. The parents present their views of joint custody where the father was worried about the lack of influence he had on the child's upbringing.

The saddest thing about it is that Ema didn't try to stop that joint custody. It didn't seem to trouble her, she was used to it.... it bothers me, I don't know, that my wife is bringing Ema up alone and takes no notice of what I think... Ema could be at nursery school in town, at school, so it wouldn't be a problem. And then there was the money, too. There were like three reasons why she wanted that care, to have custody of Ema. Yes, sometimes it makes me sad. And then there was that scene, I thought it was pretty childish, that I was accused of having his overalls at home. And she (the mother) explained that I had to return everything, socks and all that, dirty. I told her it was normal for me to wash them. ... I wasn't above doing it. I just wanted everything to work out amiably and normally, I guess. I realise now that that's the way it has to be, that she has her in her care. Joint custody, what a thing. There's always some perks and that to joint custody. (F1)

The mother mentioned disagreements over caring for the child when she was ill, during the school holidays, and was also dealing with the child's current upbringing. So, she regretted agreeing to joint custody.

When I can, when I don't have to put her in nursery school (laughs), so I don't put her there. If I can have her after lunch, then I do, so she's not away somewhere so much.... it used to bother me that I was always at home with her and he didn't give me anything extra, not even when she was sick, or during the school holidays. And he really took everything for granted. I was always at home, so of course I didn't tell him that I can't. Obviously the most important thing for me was that I could be with her and I was so happy that I at least had more chance to spend time with her. So she was really little for joint custody, I think that's the most important thing.... her dad didn't have time to look after her during the school holidays and I just got annoyed... joint custody can work either with children that are old enough (emphatic) or when the parents communicate normally and live just across the street and can see each other on a normal basis. But I think it was a big mistake, what Idid. (M1) 
Joint custody worked the best for family 2 . The parents had agreed on clear rules and everything worked. The mother spoke about possible problems that could arise. The mother predicted disagreements in their relationship in the future due to the change in both parents' incomes.

Money's such a potentially explosive topic with us. So about those real options, it's not going to be down on paper any more, it's been clear up to now, but it won't always be. It'll be about how well we trust one another. (M2)

The father from family 3 had not seen his children in almost a month; he and the mother disagree about the older child's school attendance.

So she said I'm going to put the little one in nursery school in the village, and I have no idea how I'm going to manage to get her to school in another village. It can't work like that. It used to work, when I was out of a job, it worked. And it worked when I was working, at the beginning anyway, at least until that September when she gave birth.... just think, I've not had them for a month. Now I'm going there on Friday and I'll have them for Friday, Saturday and Sunday, the first time in a month. I wanted to see them last week, as Anna had a performance on the Saturday, so I said fine, I'll take the little lad, anyway, and then yesterday I found out that they'd gone away.... she takes him away and then says you never go for him, and I don't, because I go to work, and you're supposed to give them to me when I've got some free time. (F3)

The mother was not convinced that joint custody was a suitable form of upbringing. The mother insisted on handing over both children to the father, and if not both, then he wouldn't have any contact with one of the children.

(M3) ... So many times I wanted to cancel it... ... he remembers that he wants the children. So I tell him: "Why don't you write me one or two days beforehand? Because I have something planned for us and I can't cancel it now, as we're on the way." But, I'd forgotten than on February 14th we were supposed to go to a ball with my husband, but I got the dates mixed up, and had agreed to go to the carnival. And so if I could give him Kuba. I told him: "Yeah, Kuba, sure, but you've got two children, not just one." And so I didn't give him to him.... he wanted it, too, that was twice he just wanted Kuba.... so he owes me 4 thousand. ... and I want to change the rate for that money, too. I'd want to cancel joint custody and have them just with me. (M3)

Family 1 in particular mentioned differences in the parents' style of upbringing.

... It's me that has to take the strong hand with Ema and I feel that he's too free in her upbringing. (F1)

... he (the father) is a stickler... My mum's very bossy too, so I'm completely the opposite, as I know there's no point to it. (M1) 
Parents 2 share the same main ideas about upbringing, where unity between the parents is important.

So when we both have the feeling that one child needs pushing, against his will, as it's for his own good, I still know that I always have to discuss it with the father.... we're different people, so we don't have the same ideas about how to treat the children. (M2)

You need to tell the children what's what sometimes, and stand up for the other parents, so that those kids can't take advantage of it. We're always working with them, actively. Well, we wanted children, we got them, so we have to look after them.... that conflict in our upbringing, it was always kind of a problem. My wife's really liberal in how she raises the kids. We both know that it's bad to make threats, that that's not how we should bring them up. (F2)

In families 1 and 3 there was a possible influence exerted by those in the vicinity as regards how the parents brought up their children. This was not the case, however, with family 2 .

... the way it is in the village these days, and pressure from people around you...... they don't really understand joint custody, they think that if someone has joint custody, it means you're a bad mother. I think the pressure around has made them change their views... Otherwise, I think that there's no sense in forced joint custody as such. She was fine at nursery school, and then they told me she was a lot more cheerful, I don't know. She seemed the same to me, anyway. (F1)

I tried to back it up for a while in the eyes of the people we know.... he cares so much about what the neighbours think. (M1)

As, you know the way it is, otherwise he approves everything, not her. When he says no, she says no. (F3)

Oh, and it also bothered me that she (the father's girlfriend) bursts into our lives, says her piece. My husband did nothing about it, in fact, you two have to sort it out between yourselves, he said. He didn't get involved. He didn't like it, but he didn't get involved in it. (M3)

It may also be said that the most significant problems between the parents lie in the differing influences and views of upbringing the parents have, a fact which was also reflected in the testimonies of the research participants. Where there are precise rules governing joint custody, and where communication between the parents is positive, the parents also tend to have similar styles of upbringing (family 2). 


\section{Summary and conclusions of the research}

Joint custody is one of the options for caring for children following a divorce. If this option is chosen, both parents still have as much contact as possible with the child, as was the case when the parents lived together. Both parents thus have a say and an interest in the upbringing of the child with this form of custody. However, this interest is not a weapon to be used against the other parent, nor should it be a concession on the part of one of the parents. Analysis of the significant findings presented in this research has resulted in the creation of the joint custody model we present below.

\section{Chart 1}

Joint custody/upbringing model

\begin{tabular}{|l|l|}
\hline $\begin{array}{l}\text { Child's position in joint custody } \\
\text { Opinions } \\
\text { Feelings }\end{array}$ & $\begin{array}{l}\text { Real form of joint custody } \\
\text { Practical working of joint custody } \\
\text { Changes in behaviour } \\
\text { Needs }\end{array}$ \\
\hline $\begin{array}{l}\text { Mother's position in joint custody } \\
\text { Other children } \\
\text { New partner }\end{array}$ & Joint custody \\
\hline $\begin{array}{l}\text { Father's position in joint custody } \\
\text { Preserving the family } \\
\text { New partner }\end{array}$ & $\begin{array}{l}\text { Parental agreement about joint custody } \\
\text { Communication }\end{array}$ \\
& $\begin{array}{l}\text { Information } \\
\text { Rules } \\
\text { Divorce } \\
\text { Expectations }\end{array}$ \\
\hline
\end{tabular}

Just when thinking about potential suitable forms of custody there is the need to answer some important questions and find the necessary information, or to know how to ask for that information. When looking for information, a great deal of which is available on the internet, for example, it is essential to filter that information. Examples of good practice can be found in the mire of negative stories about joint custody. It is these examples that should be given more attention in the media, and people should hear more about them. It is essential to always consider this form of custody on an individual basis.

There are several conditions stipulated for joint custody. Ideally, the parents should sit down together and consider whether they are really able to meet those conditions, always with the child's interests in mind. The parents in particular should be aware of the child's opinion, as should other institutions that come into contact with the family, such as social workers and the court. What might work well in one family could prove to be a problem with another. Boundaries and rules play an important role, and should 
be clear and comprehensible to everyone involved in joint custody (the father, mother and the child). Other close family members and relatives should also be informed of those rules so as to prevent any adverse impact on the children and, thus, on the family as a whole. Rules may also be set out in writing.

Open communication between the parents and the children forms the basis for other relationships to work better in the future. Unity between the parents gives a feeling of certainty to the children, as well to the parents themselves. Children and parents have need for certainty and certain stereotypes. The parents pass their upbringing and behavioural model on to their children. For most parents communication is an important aspect, and works better for some than it does for others. If any disagreements arise, they should be resolved as soon as possible, or professional help should be sought (e.g. counselling, mediation centre, etc.).

After carefully considering whether the model can work, an application may then be filed with the court requesting its approval of an agreement to place the child into the joint custody of its parents. Depending on its workload, the court should base its decision not only on the agreement made between the parents, but also after thoroughly questioning them and speaking with the child, where appropriate.

The research also showed that in order for joint custody to work it is essential for the parents to agree on rules they will both follow, such as financial matters (allowances for the child, tax rebates), living (the child's registered address, the parents'living in the vicinity), and exceptional situations (if the child is ill, Christmas holidays), etc. It is not in the court's power to cover all of these issues in its final decision.

The research showed that one reason for the failure of joint custody was poor communication between the parents. Various changes also occurred in the families we researched after the introduction of joint custody. In particular there were changes in the children's behaviour, such as a fixation on their mother, impulsiveness, heightened sensitivity, a tendency to cry, etc.

Joint custody cannot be assessed in general terms; it is always necessary to take into account all the circumstances in that particular family in order to decide what is in the best interests of the child and not the parents.

\section{References}

Amato, P., R. (2010). Research on Divorce: Continuing Trends and New Developments. Journal of Marriage and Family, June 2010. 72, 3, 650-666.

Czech Republic. Act No. 89 dated 03 April 2012, Civil Code. In Sbírka zákonů České Republiky. 2012, part 33, pp. 1026-1365. 
Hrušáková, M. \& Novák, T., (1999). Reálně o společné či střídavé porozvodové výchově. Bulletin advokacie, Praha: Ústředí čs. advokacie, 29, 3, 30-34.

Klimeš, J., (2009). Střídavá výchova a styk s dítětem po rozvodu. In Události a názory, Praha. Available at: http: /clanky/psychologie/stridava_vychova.pdf

Luňáčková, O., (2011). Muži versus ženy - právní úprava střídavé. Právo a rodina: rodina, manželství, děti a mládež, dědictví. Praha: Linde, 12, 10, 16-19.

Špaňhelová, I., (2010). Dítě a rozvod rodičů. Praha: Grada Publishing.

Warshak, R. A., (1995). Revoluce v porozvodové péči o děti: otcovský faktor a mystika mateřství. Praha: JAN.

Zakouřilová, E., (2014). Speciální techniky sociální terapie rodin. Praha: Portál.

\section{Contact:}

doc. PaedDr. Adriana Wiegerová, PhD.

Mgr. Dana Hamplová

Ústav školní pedagogiky

Fakulta humanitních studií UTB ve Zlíně

Mostní 5139, 76001 Zlín

tel.: +420602719104 